\title{
Interaction of Foreign Visitors of the EXIT Music Festival with Domestic Visitors and Local Population
}

\author{
Lolita Zakić'", Anđelija Ivkov-Džigurski', Nevena Ćurčić' \\ Received: December 2008 | Revised: March 2009 | Second Revised: August 2009 | Accepted: August 2009
}

\begin{abstract}
The EXIT Music Festival has been held annually in Novi Sad since 2000. Owing to its excellent organization, it has become popular among the youth population around the world. Moreover, it succeeded in attracting a large number of foreign visitors after long years of their absence in the streets of Novi Sad, which also created a basis for the research of their relations with the local population and the interrelation of their cultural and social influence.
\end{abstract}

The paper presents the evolution process of the Music Festival with a special emphasis on the opinions of both foreign and domestic visitors about their mutual interrelations, as well as the opinion of the local population about the foreigners visiting Novi Sad during the EXIT Festival.

A questionnaire conducted in 2006 on two sets of samples, one of 200 respondents in the EXIT campsite, and the other of 100 inhabitants of Novi Sad also suggest a starting point for further research in the aforementioned interaction among the visitors, as well as for a study of the relationships between the local population and the festival visitors. This was also the aim of the paper.

Key words: EXIT Festival, tourist events, youth tourism, Novi Sad

\section{Introduction}

It was at the beginning of the $20^{\text {th }}$ century when the first papers exploring the relationships of the visitors and the local population appeared within the scope of sociological research. However, contemporary researches of the relationships commenced in the late 1980 s, after the book of V. L. Smith "Hosts and guests" was published in 1977, rendering a detailed analysis of the phenomenon. The first researches highlight the fact that the relationship between the foreign tourists and the local population is temporary and most probably unrepeatable. Therefore, the emphasis is not given to the effects that provoke the contact (Cohen, 1984). There is a prevailing attitude in contemporary comprehension of the relationships between foreigners and local populations, that their contact and communication from the aspect of integration evoke a whole range of positive effects, which have had favourable influence in meeting certain cultures, knowledge exchange and enhancing the awareness of diversity and similarities of different nations. The cross-cultural relationship in tourism is well examined by Reisinger and Turner (2003), who pointed out that studies on culture are significant because a certain country presents itself to visitors through different cultural factors such as entertainment, hospitality, food, drink, architecture, handcraft, history, language, religion, education, humour, tradition, music, art and dance. All these factors have a great impact on tourism policy, planning, development, management and marketing. Through tourism and the process of globalisation, diverse cultures are brought together more and more. The quality of interaction between hosts and visitors contributes to their experience and perception of the visited destination. Therefore, many elements of national cultures (values, norms or rules) have a considerable impact on tourists' behaviour, their holiday expectations, satisfactions and consequently, repeat visitation (Reisinger and Turner, 2003). The study of the expe-

1 Department of Geography, Tourism and Hotel Management, Faculty of Science, University of Novi Sad, Trg Dositeja Obradovića 3, 21000 Novi Sad, Serbia

* Corresponding author: Lolita Zakić, e-mail: Iolita.zakic@dgt.uns.ac.rs; Co-authors: Anđelija Ivkov, e-mail: ivkova@uns.ac.rs and Nevena Ćurčić, e-mail: galant@ptt.yu 
rience of foreign visitors to the EXIT music festival showed that repeat visitation and coming to the Festival by recommendation of friends were frequent, as follows from the analyses of the research conducted at one of the most popular and visited music festivals in Europe. Moreover, the interaction between young people from Serbia and many countries all over the world, created positive exchange of cultural elements, which contributed to better understanding of different cultures. This fact was of great importance for Serbia, as a country known by the recent wars on the Balkan and political conflicts, because it showed that a well organized cultural event such as the EXIT music festival, can improve the image of Serbia, attract more foreign visitors year by year and make potential tourists interested in other events and tourist destinations in Serbia. Therefore, it is noticeable that the strengths of festivals and events in contemporary context, lie in their ability to congregate masses of people together under circumstances where they can share experiences and learn to look at the world through the eyes of others (Bjeljac and Curcic, 2005).

A global urge for immediate communication between different people (members of different races, nations, religions and cultures) may be labeled as cosmopolitism. Within their mutual interrelation, a tourist and a host tend to communicate and overcome the obstacles that separate them, which in time may lead to homogenization, i.e. loss of differences, which is considered a negative influence by numerous scientists (Čomić, 2000). However, the fact that today's tourist festivities became very popular among the contemporary special events as tourist attractions with the higher level of progress (Getz and Chayne, 1997), proves their significance. Therefore, their role is very important in exchanging culture and customs among the different social groups (Bjeljac and Curcic, 2007). The example of the EXIT Festival primarily emphasized positive aspects of mutual interaction, which was supported by the findings of the questionnaire conducted in 2006.

\section{Evolution of the EXIT Festival}

The EXIT Festival phenomenon was related to the activities conducted in October 1999 as a way of protesting against difficult social and political situation in Serbia for almost ten years. The idea of organizing a music festival came into being at the beginning of July 2000, when over 120 students organized a huge multimedia performance (concerts, debates, plays and films) which lasted for 100 days. The basic idea of this important event, primarily from its social and political aspect, was to launch young people as the introducers of democratic changes who would influence the creation of better society for the whole country, finally came into being. The following years brought favourable conditions for the EXIT Festival to gain more entertainment features with indispensable educational content, thus becoming a symbol of positive spirit, which would attract young people from all over the world and improve tourist flows in Novi Sad at the same time (Golić, 2003).

More than 600 hundred people of different professions, mostly in media, marketing and management sectors, but

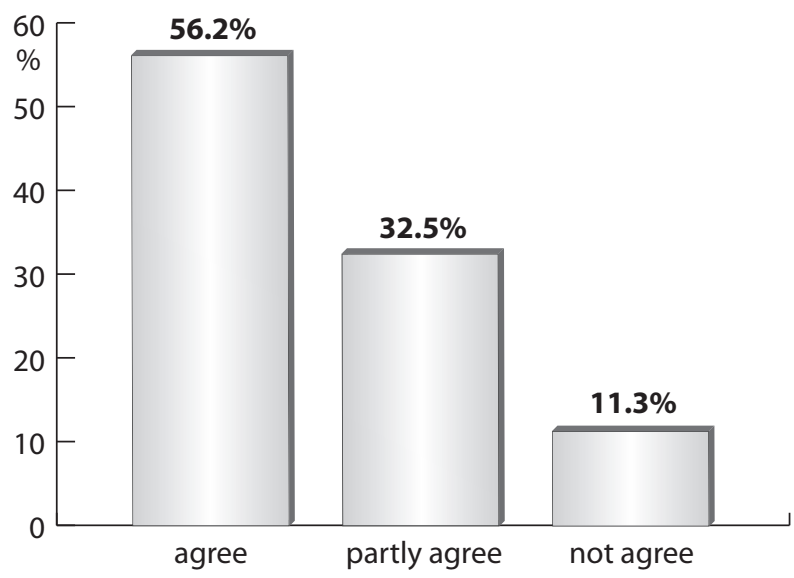

Figure 1 Respondents' answer to the question: Does the EXIT positively contribute to opening of Serbia to Europe and the world?

Source: Media announcement of "TIM" Marketing agency, 2006

also in sociology, psychology, music etc. participated in the EXIT Project realization in 2001. The venue was moved to the Petrovaradin fortress, which became one of the synonyms for the event, thus confirming the ideal selection of the location, capable of hosting numerous stages with affluent contents. Owing to a large number of foreign performers and visitors, the EXIT gained international character and attracted over 250,000 visitors. In addition to high quality of music, theatre and film programme performed at seven different stages during nine days of the festival, the audience was able to enjoy in concerts, plays, films and special debates with celebrities. The successful first realization of the project of such type launched the EXIT among key cultural events in the country, with the tendency to be broadened to regional and European level due to the variety and affluence of the content.

The following year 2002, brought the increase in the number of visitors to 350,000 . The number of foreign and domestic journalists reporting from the festival was 1,200 , which largely contributed to the popularity of the EXIT at home and around the world. During the nine days of the Festival, numerous surveys were conducted, in which the visitors expressed their opinions upon the EXIT Festival. Over $80 \%$ of the respondents have never attended such a music festival, but they referred to music programme, entertainment and socializing as the main reasons for their arrival (www.exitfest.org) Promotion and propaganda that were conducted by the organizers of the EXIT by means of various audio-visual media (TV and radio commercials and jingles), internet presentations, graphical aids (posters, billboards, prospects and postcards), as well as public relations (participation of organizers in various TV shows and press conferences) contributed to increasing popularity of the event. Consequently, the following year 2003, brought more foreign visitors to the festival. The highest number of visitors arrived from former Yugoslav republics, then the neighbouring countries (Hungary, Slovakia and Greece), followed by significant number of visitors from Sweden, Finland, England and the USA. Both the or ganization quality and the performers who mainly claimed to have performed the best in their careers, reached the enviable level. It certainly attracted famous world media centres, such as MTV, which commenced the project on raising awareness 
Table 1 The number of tourists in Novi Sad and the visitors to the EXIT Festival (2001-2006)

\begin{tabular}{|l|r|r|r|r|}
\hline & $\begin{array}{c}\text { Official } \\
\text { number } \\
\text { of foreign } \\
\text { tourists }\end{array}$ & $\begin{array}{c}\text { Official } \\
\text { number of } \\
\text { domestic } \\
\text { tourists }\end{array}$ & $\begin{array}{c}\text { Official } \\
\text { number of } \\
\text { tourists in } \\
\text { total }\end{array}$ & $\begin{array}{c}\text { The } \\
\text { estimation of } \\
\text { the visitors to } \\
\text { Exit Festival }\end{array}$ \\
\hline 2001 & 18.791 & 80.481 & 99.272 & 250.000 \\
\hline 2002 & 23.016 & 69.476 & 92.492 & 350.000 \\
\hline 2003 & 24.399 & 48.914 & 73.313 & 140.000 \\
\hline 2004 & 24.671 & 41.108 & 65.779 & 150.000 \\
\hline 2005 & 28.980 & 38.666 & 67.646 & 150.000 \\
\hline 2006 & 35.370 & 39.198 & 74.568 & 150.000 \\
\hline
\end{tabular}

Source: Zakic, 2006; www.exitfest.org; Statistical Yearbook, 2007

about trafficking in the region, which supported the affirmation of the EXIT in the field of social development and education of the youth. The EXIT Festival in 2004 and 2005 followed the same quality pattern in terms of programme, organization, number of participants that exceeded 150,000 and even larger number of foreign visitors (www.exitfest.org).

More detailed information on the structure of visitors, whose number in 2006 was around 150,000 were obtained in a broad research of Novi Sad marketing agency „TIM“ conducted on the sample of 1,300 respondents. According to the research, $27 \%$ of visitors in 2006 were foreign visitors, with the highest share of British (8\%). Among the domestic visitors, the highest share had Novi Sad (26\%). Although the organization and the programme of the Festival appealed to both foreign and domestic visitors most, their opinions about prices, services and products differed. While the majority of foreign visitors highlighted low prices as the advantage of the event, $56 \%$ of domestic visitors complained about high prices of refreshments. According to this survey, foreign visitors consider the EXIT Festival as a good quality music programme and socializing, highlighting its status in Europe as insufficiently recognized.

The organizers themselves emphasized that the obtained data confirmed the quality of the festival, according to them, as "an economic, tourism and cultural asset" for the town of Novi Sad and the country as well (public announcement of Marketing agency “TIM", 2006).

\section{Social and Cultural Relationship between Foreign and Domestic Visitors}

Culturally specific features that are reflected in distinctive tradition, language, handcrafts, gastronomic features, music and architecture of various tourist destinations have become significantly growing motives of tourist visits, especially when increasing globalization and similarity of contemporary living styles are considered. High interest of visitors in culture and customs of the local population in a tourist destination are superbly achieved in their direct contacts, which further contribute to integration, familiarization and socialization of different nations (Čomić, 2000).

Mutual social and cultural influence is inevitable in the course of local population and foreign tourists'contacts, since the tourist movements contribute to meeting different societies and areas, with a highly altering level of their differences.
However, the emphasis should be given to the tourists' behaviour during a visit to a destination that frequently does not reflect their ordinary lifestyle. It means that tourists' behaviour seems more relaxed during holidays, which is perceived in wearing casual clothes, increased food and beverages consumption, as well as in the trend of getting more entertainment. Such behaviour commonly creates a negative image of the country of their origin for the local population (Williams, 1998).

The acceptance and tolerance of tourists by a host community has been acknowledged as being vital for a successful tourism destination and is one of the major factors in tourists deciding to return to a destination, or to recommend it to friends (Lawson, Merrett \& Williams, 1996).

According to Williams (1998), each arrival of foreign tourists in a local community inevitably provokes positive and negative influences that depending on the number of visitors and levels of their differences may be more or less prominent. The main positive influences refers to the increased knowledge and understanding of hosts societies and cultures, promotion of the reputation of the hosts in the world community, introduction of new values and habits practices, as well as the revitalization of traditional crafts, performing arts and rituals. Among the above-mentioned positive effects, the Exit music festival proved that the interaction between foreign and domestic visitors resulted in better understanding of Serbian culture and hospitality, increased knowledge about the country and people and meeting their habits. On the other hand, negative effects pointed out by Williams, such as debasement and the commercialisation of culture, removal of meanings and values associated with traditional customs and practices, increased tensions between imported and traditional lifestyle, erosion in the strength of the local language, new patterns of local consumption and risks of promotion of antisocial activities (gambling, drugs, violence, etc.), have not been noticeable in the case study of the EXIT music festival. What's more, the research has confirmed the production of many positive effects in mutual interaction between hosts and visitors, whereas negative effects were not significantly recognizable. These statements are supported by the questionnaire surveys conducted at the Festival in 2006, as follows in the results of the research.

\section{Results of the Research and Data Processing}

\section{Main tasks and aims of the research}

The main task of the research was to show the level of interaction between the foreign and domestic visitors to the EXIT Festival, as well as the attitude of local citizens to the Festival and foreigners. Moreover, the willingness to meet and interact with each other was also the question of interest for further research on the relationship between foreign and domestic visitors. Gaining knowledge about whether foreign and domestic visitors was interested in finding out information about each others' culture and tradition was also the aim of the research.

The main goal of the paper was to find out the mutual opinion of domestic and foreign visitors in order to prove 


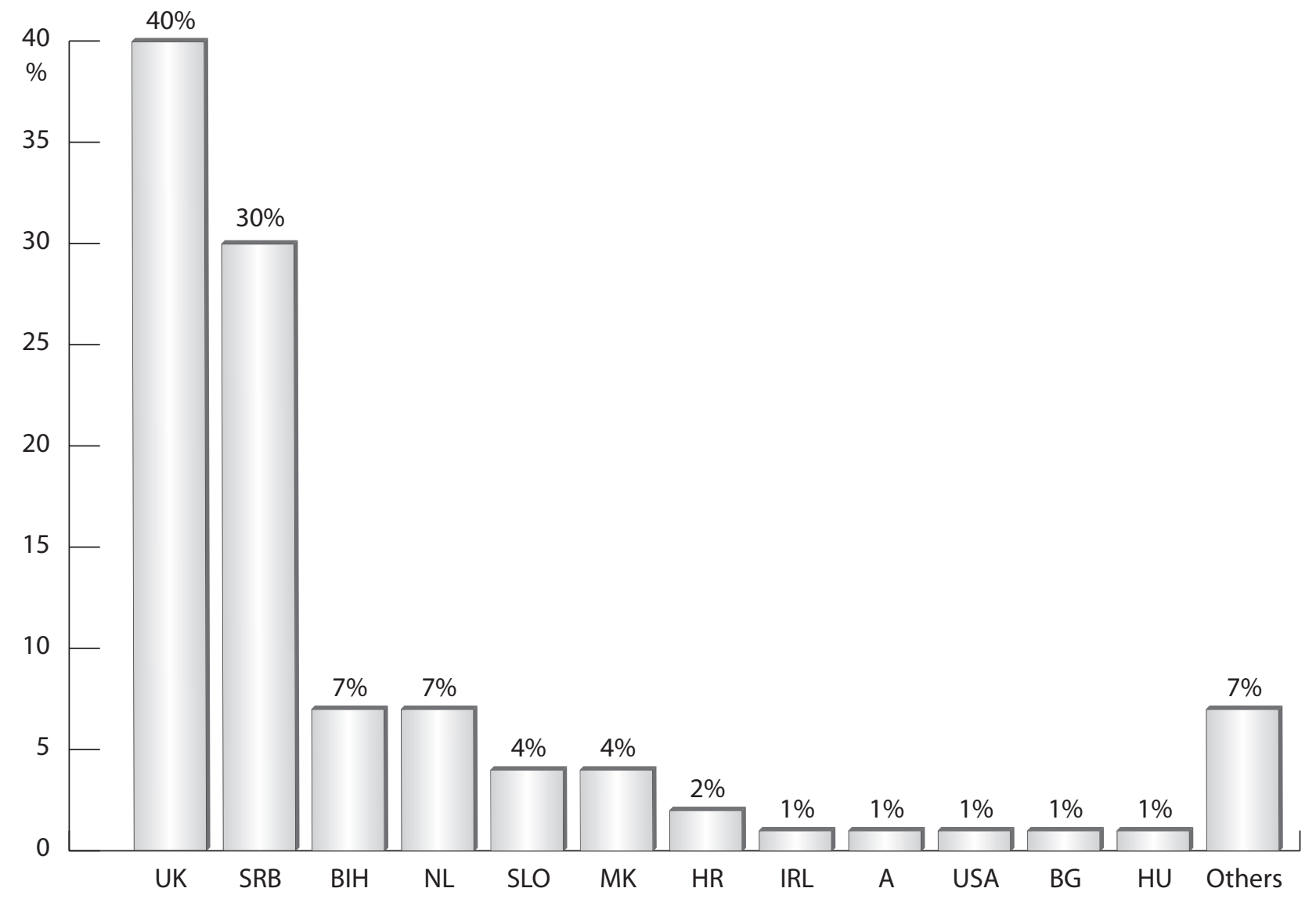

Figure 2 The number of visitors at the EXIT camp by countries in 2006 Source: Official statistic of EXIT campsite, 2006

whether they are ready to interact with each aother. Finally, finding out the willingness of foreigners to visit Serbia again, was one of the aims of the research as well.

\section{The sample of the research}

Survey was mostly conducted in the EXIT camp, where visitors from Europe, America and Australia were accommodated. Within the camp, they had the opportunity to socialize and provide answers to the questions asked in the survey. The questionnaire consisted of 13 questions, which the respondents answered on the spot, adding extra information or commenting according to their impressions. The paper renders statistical analysis of the data and their description on the appropriate sample of 100 foreign and 100 domestic visitors of the Festival. Apart from that, the survey was also conducted in Novi Sad where 100 local respondents were surveyed according to the same principle of the questionnaire.

The total number of visitors in the EXIT camp in 2006 was 4,718 , out of which 1,429 visitors arrived from Serbia (30\%). The remaining number of foreign visitors arrived from different countries, mainly from the Netherlands, Bosnia and Herzegovina, Slovenia, FYR Macedonia, Ireland, etc. (Figure 1).

\section{Impressions and attitudes of foreign visitors to the EXIT Festival}

The structure of the foreign respondents shows, that out of the total of 100, more than half arrived from the UK (55), then followed the young population from former Yugoslav repub- lics (11), Australia and New Zealand (9), Hungary, Greece, the Netherlands, Norway and other European countries. The majority of the respondents (77\%) were first-time visitors in Serbia. From the aspect of widening positive opinion about the Festival and Serbia abroad, there was a significant percentage of visitors arriving to the EXIT due to their friends

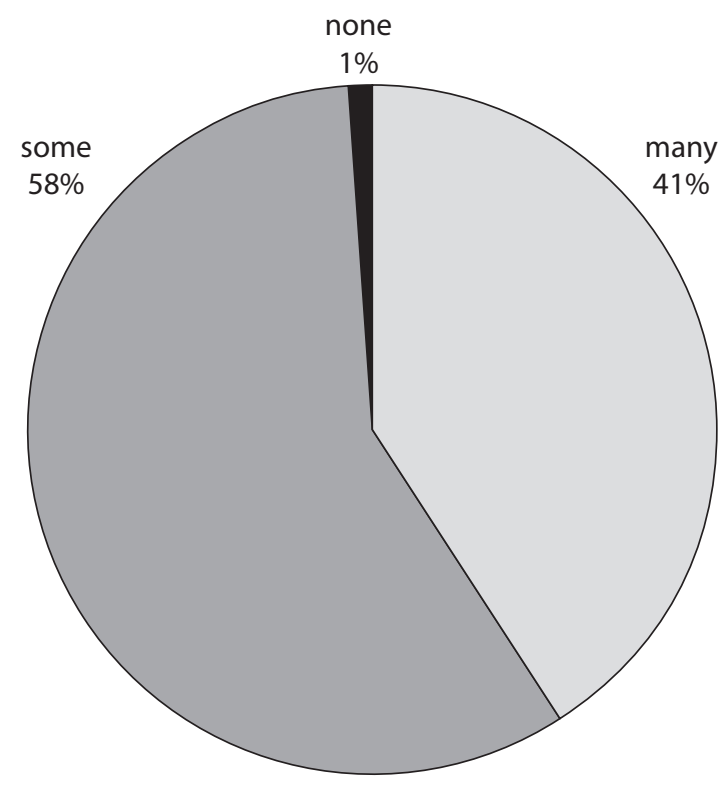

Figure 3 The percentage of local visitors that foreigners met at the EXIT Festival

Source: Questionnaire conducted by the authors of the paper, 2006 
proposal (65\%), whereas others were informed through the Internet (20\%), radio (10\%) and TV channels (5\%).

Half of the respondents were students (51\%), then the employed (46\%) with mean age of 23.6 of all visitors.

Almost all foreign visitors had a chance of meeting some domestic visitors, the deviation was only in the number of new acquaintances, $58 \%$ of foreign respondents met only several domestic visitors, whereas $41 \%$ of foreign respondents met many domestic visitors. The percentage of foreign visitors who returned to their countries without meeting any local visitors was only $1 \%$. The impressions of foreigners concerning the behaviour and attitude of domestic visitors were mainly positive (Figure 4). Additional opinions of foreign visitors about domestic visitors included the following: friendly, hospitable, nice, like to have fun, and seem happy. Mixing with domestic visitors most of foreign visitors found useful to learn about Serbia, its culture and customs, whereas only $6 \%$ of foreign visitors exhibited low level of interest in learning something about Serbia.

Apart from the direct contact of foreign and domestic visitors to the Festival, significant segment of the research was the part referring to the level of satisfaction of foreign visitors with their experiences during their stay, as well as their knowledge of Serbia prior to the arrival. Results of the respondent's overall perceived level of satisfaction with the Festival organization indicated that $72 \%$ of respondents were satisfied, which may further influence the positive image of Serbia abroad and consequently the increased arrival of visitors in the following years.

Not only the Festival organization, but also the unique advantages were the hospitality of hosts and opportunities of meeting new people were highlighted by $40 \%$ of the respondents.

As far as the knowledge of other places and tourist attractions in Serbia is concerned, it should be emphasized that $81 \%$ of respondents are familiar with Belgrade only, whereas other towns, mountain and spa centres, were known to an insignificant percentage of respondents (under 10\%), mainly from former Yugoslav republics. The only association with Serbia that all the respondents were familiar with was the war in the near past. On the one hand, the war relatedness had negative influence on the opinion of foreign visitors concerning Serbia in general. On the other hand, the figures that $86 \%$ of the respondents would visit the EXIT the following year and $39 \%$ of the respondents would visit other destinations in Serbia, prove that meeting and socializing with domestic visitors, foreigners receive positive image of the mentality of the local population. Thus, it may be concluded that through this they receive encouragement to visit other tourist destinations in Serbia (Questionnaire survey, 2006).

According to the results of the survey, it is obvious that foreign visitors were eager to meet domestic visitors, share their views with them and learn about the culture and habits in Serbia. Similarly, the survey conducted in Australia at the sport event, which gathered different nations from all over the world, showed that the respondents with dissimilar cultural backgrounds were more likely to agree that learning about specific cultural aspects were important. These findings demonstrate the role of culture within the context of in-

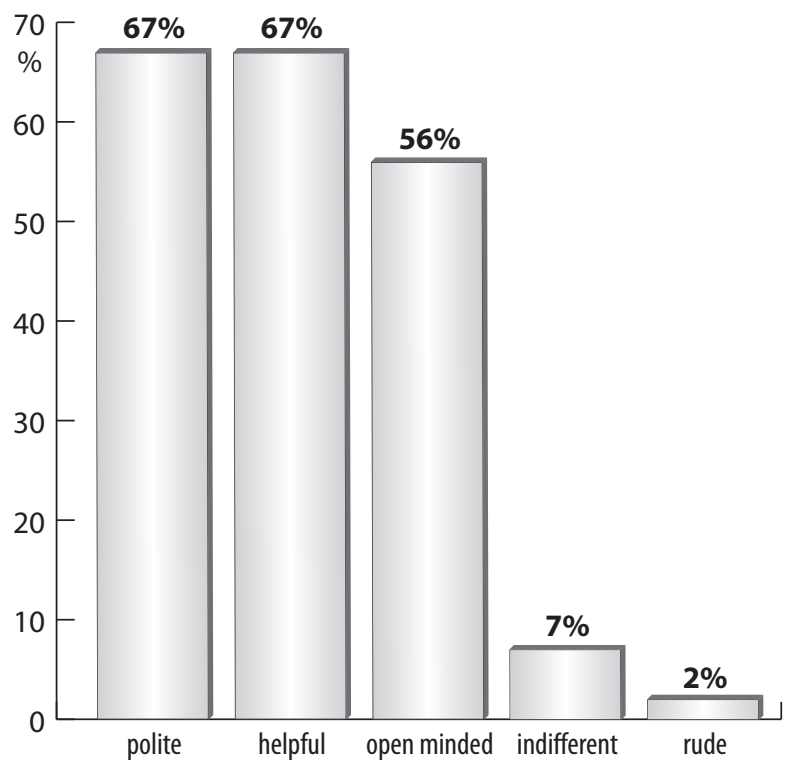

Figure 4 Opinions of foreign visitors about domestic visitors to the EXIT Festival

Source: Questionnaire conducted by the authors of the paper, 2006

ternational events and validate the use of Hofstede's (1980) cultural clusters in comparing cultural based variables (Funk and Bruun, 2007). Moreover, the fact that the majority of foreign visitors would come to the Festival the next year, willing to recommend it to their friends, proves that they had a great time and liked the atmosphere, as well as the hospitality of the locals. These aknowledgements are very significant not only for the Festival itself, but also for the future development of tourism in Serbia. Namely, the positive attitude about the Festival and the intention of foreign tourists to revisit Serbia are esential for building up the image of Serbia as a tourist destination, which was distorted by the unstable political and economic situation during the 9o's.

\section{Opinions of Domestic Visitors about Foreign Visitors to the EXIT Festival}

Domestic visitors of the EXIT Festival also expressed their opinions on the foreign visitors in the questionnaire. The importance of expressing the attitude towards the foreign young population visiting the event was highlighted by the fact that majority of domestic young population had the first time opportunity to meet foreign people, since they did not have the possibility of travelling abroad and experience the relationships between local population and tourists there.

The structure of domestic visitors was similar to foreigners' which means that the mean age of 100 respondents was 23.5, whereas there are deviations in the number of employed and students. Explicitly, the dominance of students and pupils was observed within the domestic group of respondents $(71 \%)$, whereas the employed made only $21 \%$, which made a half of the percentage within the foreign group of respondents. Almost half of the domestic respondents (44\%) arrived to the Festival from Novi Sad and Belgrade and the remaining percentage from other places in Vojvodina and Serbia. A major aspect of integration with foreign visitors for Serbian young population was the knowledge of foreign languages, as a base for successful communication. 


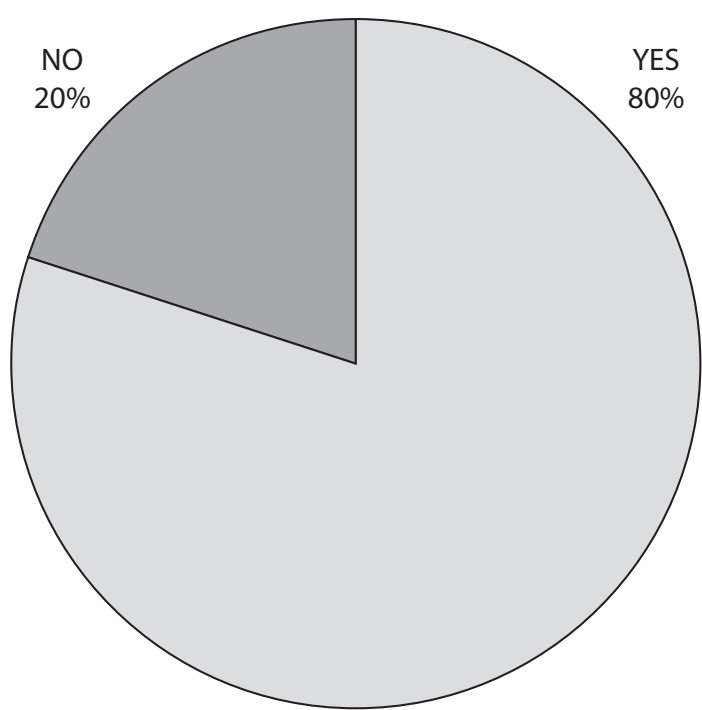

Figure 5 The answer to question if the serbian visitors have found out something about the culture of foreign visitors to the Exit Festival

Source: Questionnaire conducted by the authors of the paper, 2006

Majority of the respondents reported to speak excellent English (34\%) or to have average knowledge of English (51\%), whereas a smaller number reported the knowledge of other foreign languages: French, German, Spanish, Swedish, etc. The findings demonstrate that foreign language knowledge was not a restrictive factor in socializing domestic and foreign visitors to the EXIT Festival. It has to be noted that $78 \%$ of the respondents answered that they met foreigners from different countries. The opinions reported by the domestic visitors upon the foreign visitors were the following: friendly (65\%), open-minded (40\%) and polite (38\%), followed with $3 \%$ as non-communicative, or rude (6\%). Individual remarks of respondent also included attributes civilized and cheerful.

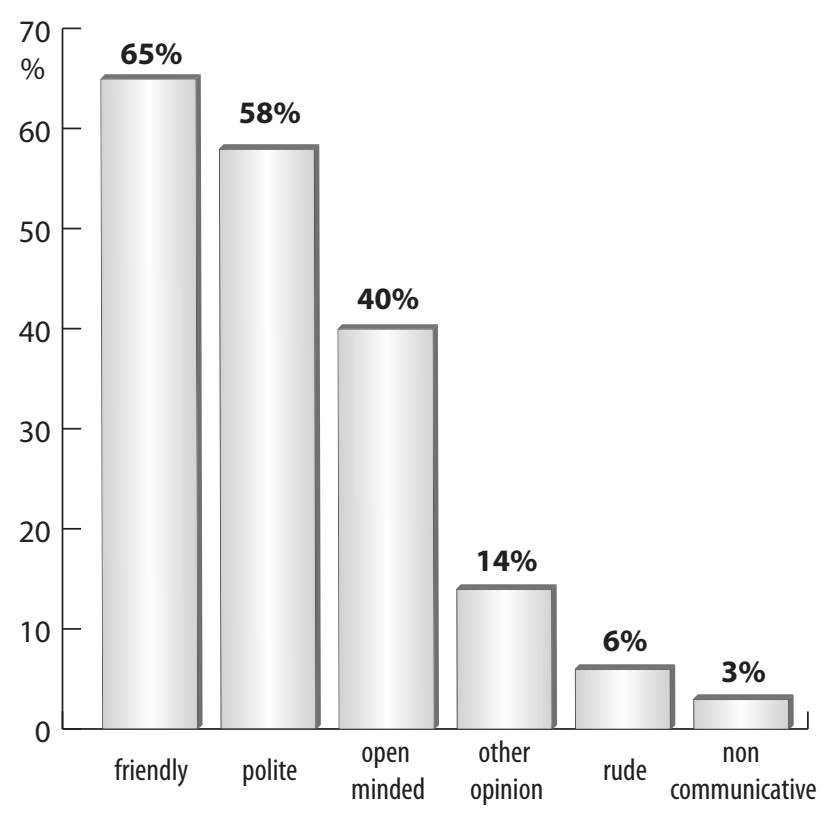

Figure 6 Opinions of domestic visitors about foreign visitors to the EXIT Festival

Source: Questionnaire conducted by the authors of the paper, 2006
To the question whether foreign youth are more openminded than Serbian youth, majority of the respondents reported that the open-mindedness is almost equal, only a small percentage (9\%) experienced foreigners as unapproachable, followed by $31 \%$ who reported that foreigners are more open-minded. Mainly the respondents who had travelled abroad and made contacts with foreign people held such opinion. Through socialization with foreigners, most of the domestic visitors (80\%) learned about culture, customs and the foreign country, whereas a certain number of domestic visitors (20\%) reported low interest in obtaining the information.

Young population group who responded that they did not have the opportunity to travel abroad, according to the findings, learned the most about foreigners, since they were motivated to obtain knowledge about the life and circumstances outside Serbia. For many domestic visitors, coming to the festival was the first chance to intaract with young people from all over the world, so many of them took the advantage of such opportunity. From the social point of view, these contacts were useful for positive cross-cultural changes, through conversation and socialization, which helped domestic visitors to gain new experiences and knowledge about different nations and cultures. A supportive issue to the findings in the questionnaire is the fact that similar values and priorities are shared among the foreign young population, e.g. socializing, visiting new and attractive destinations, as well as high-quality entertainment. Similarly, to foreign visitors, domestic visitors highlighted the superb organization of the Festival (66\%), followed by the opportunity of meeting new people (56\%) and socializing with foreigners.

\section{The Opinion of the Local Population on Foreign Visitors and the EXIT Festival}

The structure of the respondents of local population of Novi Sad was the following: the mean age was $32,8 \%$, the percentage of employed were $71,14 \%$ were students and the rest of the respondents were unemployed. The research was conducted in Novi Sad and its vicinity, by the same principle as the research at the EXIT camp.

Novi Sad, similarly to most of the towns in Serbia, has not had the opportunity of receiving a larger number of foreign tourists in a shorter portion of time for the past fifteen years. Majority of foreign visits were business oriented or short excursions of smaller groups, being neither highly perceived by the local population, nor giving the locals the possibility of contacting the foreigners and learning about their culture. The EXIT Music Festival was the first to attract thousands young visitors not only from Europe, but also from distant continents of America and Australia. Owing to this event, the bustling streets of Novi Sad were packed with completely new vibrant atmosphere for several days, which was reported as a positive issue by the respondents.

Half of the respondents from Novi Sad and its surroundings reported that they met foreign tourists visiting the Festival. Nearly $77 \%$ of the population of Novi Sad reported the foreigners as friendly, polite and communicative, which supported their readiness to make contacts. However, there was a positive impact on population awareness to overcome the blockade and isolation towards foreign countries, 
which existed as the result of general political and social circumstances. Despite this, half of the respondents who live in Novi Sad and its vicinity reported that foreigners are much more open-minded and friendlier than domestic population, whereas the other half reported them to have approximately equal qualities.

Through their contacts with foreign visitors, the local population mainly learned basic facts about the country and the culture of the contacted foreigners. Apart from contacts, the local population perceived the advantages of foreign tourists' arrivals generally in development of tourism and money flow. They also underlined that it might "raise tourism awareness of the local population to a higher level", "diminish their xenophobia", "introduce a wealthier society", "bring cosmopolitan spirit", "develop tourism, communication, friendship", which are highly supportive issues for the positive attitudes of the local population towards the foreign visitors. Still, a small percentage of the respondents (10\%) exhibited low level of interest for socializing with foreigners, which supports the hypothesis that a certain portion of the population is unready to accept the openness towards the world being unaware of integration advantages for both individuals and the country. However, negative effects that mass events can cause to the local community, such as commercialisation of culture, decreasing the value of traditional customs and practices, promotion of antisocial activities and tensions between imported and traditional lifestyle, were not noticed by the local residents, who tried to make the best of this popular event, not only in social, but also in economic sense, recognizing its advantages. The explanation of such attitude of local community, who proved to be tolerant to the foreign visitors during the festival, probably stems from the fact that the isolation during the 90's, there were not many foreign tourists on the streets of Novi Sad, so the locals welcome the chance to meet them during the festivals and to feel the atmosphere of crowded streets of cheerful young tourists.

\section{Discussion}

Cross-cultural interaction in which the foreign and domestic visitors of the EXIT music festival took part, was very significant from different cultural and social point of views, regarding the positive experience and knowledge that both group of youngsters gained. Namely, owing to the Festival, the foreign visitors were given the opportunity to capture the real image of not only the population of Novi Sad, but also the visitors from the entire Serbia. This is essential because Serbia has been assigned a negative image within the context of war activities in the former Yugoslavia since 1992.

The negative image of Serbia has been confirmed by the data obtained in the questionnaire conducted during the Festival, where over $90 \%$ of the respondents from Western Europe, America and Australia reported the recognition of Serbia only by issues such as war, poverty, instability and aggression (Marketing agency "TIM", 2006). However, the visitors' impressions of Serbia after the Festival were completely positive, which also meant the excellent Festival, good organization and outstanding entertainment. This attitude might have a great impact on future visits of foreign

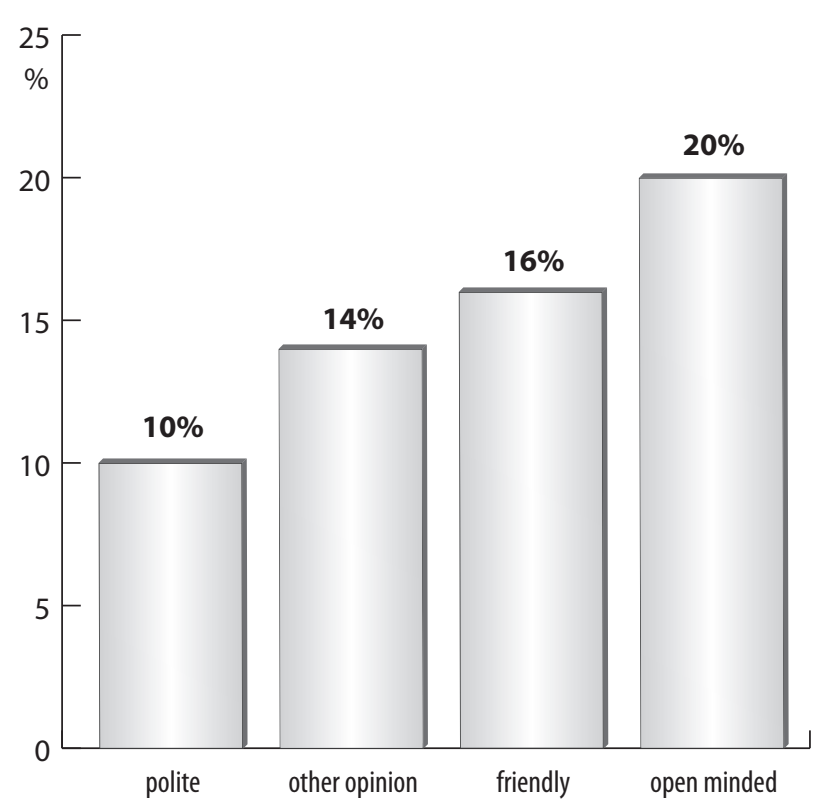

Figure 7 Opinions of the local population about the visitors to the EXIT Festival

Source: Questionnaire conducted by the authors of the paper, 2006

tourists to the Festival and Serbia as well and on spreading positive word-of-mouth, as the best marketing tool for creating a favourable image of this destination. Moreover, the

recognition of Vojvodina and Novi Sad as a well known tourist destination on the international tourist market, is possible through the promotion and sale of tourist packages and offers of the most attractive tourist products, such as the Exit music Festival (Dragin et al., 2007). Besides producing a positive image of Serbia and Vojvodina, the organization of an event such as the EXIT, created the opportunity of promoting cultural and natural assets of Serbia, which have been formerly neglected. Thus, the advantages of visiting the Festival (Novi Sad and Serbia), generally became prominent on a yearly basis related to the increase in the number of tourists. Serbia, as a novel destination on the western market with its new brand, the EXIT Festival, offers excellent low cost entertainment in authentic ambience of Petrovaradin fortress. Furthermore, Serbia was a challenge for numerous foreign visitors who received a positive feedback and turned into the best promoters of the EXIT Festival in their countries of origin. The findings of the questionnaire in 2006 also demonstrated that $65 \%$ of the respondents visited the Festival due to their friends' proposal. Generally, visitors from Eastern Europe possessed better knowledge and opinion of Serbia contrasted to visitors from Western Europe. We can say that currently less developed countries anticipate tourism as the initiator of their development (increase of employment, development of economy, income increase, especially foreign tourism, increase the national income (Ivkov et al., 2007). Positive effects of the EXIT music festival, which gathers a large number of foreign visitors, are primarily reflected within the opportunity of opening towards the world, as well as the possibility of increasing income in tourism industry which would lead to the local community development. As far as negative impacts are concerned, according to Williams (1998), such as culture commercialisation, reduction of traditional cus- 
toms significance in the local community, i.e. increment of tensions between foreigners and local population remained unnoticeable. Within the negative impacts, mass presence of young people mainly associated to drugs intake as being the case in numerous other countries, but this was reduced to minimum owing to monitoring and security.

Questionnaire survey, confirmed the customary positive effects of the EXIT music festival, especially its impact on relationships between foreign and domestic visitors, as well as broadening the awareness of the local population, whereas the negative effects were less prominent. The prevailing positive attitude that foreign and domestic visitors experienced through their mutual interaction is of great importance, not only for developing new attitudes, but also for integration of Serbia's young population with European countries and its values.

\section{Conclusion}

The importance of the EXIT Festival, due to its popularity obtained among the young population around Europe is primarily reflected in the opportunity of contact development among the foreign visitors and young population in Serbia, as well as the opportunity to introduce the local population to the main streams and aspirations of the foreign youth population. That piece of evidence unlocks the development paths and awareness broadening about similarities and differences between different nations, as well as elimination of social, religious, ethnic, racial and language obstacles.

The mainly positive impression obtained by foreign visitors during their stay in Serbia, would open new possibilities in further promotion of the Festival and Serbia in general, which would inevitably attract more foreign visitors. As the result, local population would directly experience benefits of the Festival through the revenues of tourism.

The positive impacts identified above are primarily based upon the questionnaire survey and support the significance of the EXIT Festival and its contribution to the realization of interactions' variety between domestic and foreign visitors and the local population as well.

Based on the positive experience that all the participants of the Festival had about each other's culture and behaviour, as well as on the friendly attitude that locals had about foreigners, proves that this popular Festival gives the opportunity for experiencing the destination's culture and increasing visitors knowledge about Serbia.

Finally, the fact that the EXIT music Festival became recognizable as one of the most popular events for young population all over the world, contributes to the creation of positive image of Serbia and attracting more visitors each year, giving the opportunity for new cross-cultural interactions.

\section{Acknowledgement}

The paper is a part of the Project "Demographic transition in Serbia"(Contract of the project: EVB: 146017D,) financed by the Ministry of Science.

\section{References}

Bjeljac Ž., Curčić, N. 2007. Tourist events of the West Pomoravlje Region (Serbia), Glasnik Srpskog geografskog društva LXXXVII/2, Serbian Geographical society, Belgrade, 225-240. (in Serbian)

Bjeljac, Ž., Ćurčić, N. 2005. Ethnographic Events in Vojvodina as Part of Tourist Offer, Geographica Pannonica 9, 59-64.

Cohen, E. 1984. The Sociology of Tourism: Approaches, Issues, and Findings. Annual Review of Sociology 10, 373 392.

Čomić, Đ. 200o. The Trevel Through Geopanoptikon, Federal center for the Improvement of Hotel Industry, Belgrade. (in Serbian)

Dragin, A., Dragin, V., Plavsa, J., Ivkov, A., Djurdjev, B. 2007. Cruise Ship Tourism on the Danube in Vojvodina Province as a Segment of Global Tourism. Geographica Pannonica 11, 59-64.

EXIT publication. 2002. EXIT Association, Novi Sad.

Funk, D. C., Braun, J., T. 2007. The role of socio-psychological and culture-education motives in marketing international sport tourism: A cross-cultural perspective, Tourism Management 28, 806-819.

Getz, D. 1997, Event management and Event Tourism, Cognizant Communications Corporation, New York.

Getz, D., Chayne, J. 1997. Special event motivations and behavior. U Ryan, C (ed), The tourist expirience. A new introduction, pp.135-154.

Golić, B. 2003. The analysis of Marketing Activities of the EXIT Festival in Novi Sad, Department of Geography, Tourism and Hotel Management, Faculty of Science, Novi Sad. (in Serbian)

Hofstede, G. 1980. Culture's consequences: International differences in work related values. Newbury Park, CA: Sage.

Ivkov, A., Dragin A., Kovacevic T., Djurdjev B., Ivanovic Lj. 2007. Influence of Tourism on the Employment in Vojvodina, Geographica Pannonica 11, 54-58.

Mayfield T.L, Crompton, J.L. 1995. Development of an instrument for identifying community reasons for staging a festival, Journal of Travel Research 33,3.

Okanović, P. 2006. EXITo6: Evolution of the EXIT Festival and research on public opinion. Media announcement, 27.07.2006., Novi Sad.

Pickard, D., Robinson, M. 2006. Festivals, tourism and social change, Cromwell Press, Great Britain.

Reisinger, Y.,Turner, W. L. 2003. Cross-Cultural Behaviour in tourism, Butterworth Heinemann, Oxford.

Research of the authors at the EXIT Festival, 2006.

Statistical Yearbook, 2007. Statistical Office of Republic of Serbia, Belgrade.

Thyne, M., Lawson, R., Todd, S. 2006. The use of conjoint analysis to assess the impact of the cross-cultural exchange between hosts and guests. Tourism Management 27, 201-213.

Williams, S. 1998. Tourism Geography, Routledge, New York, 150-171.

Zakić, L. 2006. Prospectives of youth tourism in Novi Sad Example of the EXIT Music Festival. Tourism 10, 48-49. (in Serbian)

www.exitfest.org 